\title{
Could an efficient WGS catalyst be useful in the CO-PrOx reaction?
}

\author{
T. R. Reina ${ }^{* 1}$, E. Papadopoulou ${ }^{2}$, S. Palma ${ }^{1}$, S. Ivanova ${ }^{1}$, M.A. Centeno ${ }^{1}$, \\ T. Ioannides ${ }^{2}$ and J.A. Odriozola ${ }^{1}$ \\ ${ }^{1}$ Departamento de Química Inorgánica, Universidad de Sevilla e Instituto de Ciencias de Materiales de \\ Sevilla Centro mixto US-CSIC Avda. Américo Vespucio 49, 41092, Seville, Spain. \\ ${ }^{2}$ FORTH/ICE-HT, Stadiou Str. Platani P.O. Box 1414, Patras GR-26504, Greece.
}

(*) corresponding author: tomas.ramirez@icmse.csic.es

\begin{abstract}
This work presents an evaluation of a high performance series of water gas shift (WGS) catalysts in the preferential $\mathrm{CO}$ oxidation reaction (PrOx) in order to examine the applicability of the same catalyst for both processes as a first step for coupling both reactions in a single process. Gold based catalysts are applied in an extensive study of the CO-PrOx reaction parameters, such as $\lambda$, WHSV, $\mathrm{CO}$ concentration and $\left[\mathrm{H}_{2} \mathrm{O}\right] /\left[\mathrm{CO}_{2}\right]$ ratio in order to obtain the best activity/selectivity balance. $\mathrm{CO}$ and $\mathrm{H}_{2}$ oxidation reactions were treated separately in order to establish the degree of $\mathrm{CO} / \mathrm{H}_{2}$ oxidation competition. Additionally the catalysts behavior in the CO-PrOx parallel reactions such a WGS and RWGS have been also carried out to analyze their effect on product composition.
\end{abstract}

Keywords: Gold catalysts, cerium oxide, iron oxide, $\mathrm{PrOx}, \mathrm{H}_{2}$ clean-up. 


\section{Introduction}

The hydrogen-fueled polymer electrolyte membrane fuel cell (PEMFC) is considered a very promising candidate to directly convert chemical into electrical energy [1]. PEMFCs appear to be a viable technology for small-scale electricity production as required for electric vehicles and residential power generators due to their advantageous features, such as low-operating temperature $\left(80-200{ }^{\circ} \mathrm{C}\right)$, sustained operation at high current density, low weight, and compactness, potential for low cost, fast start-up and suitability for intermittent operation [2]. These small-scale units depend on processing a hydrocarbon fuel for producing a $\mathrm{H}_{2}$-rich product that fuels PEMFCs. Fuel processors convert liquid hydrocarbons, the volumetric energy content of which is much larger than that of bottled hydrogen, into an almost $\mathrm{CO}$-free $\mathrm{H}_{2}$-rich product through the coupling of several catalytic reactions, such as reforming, usually steam reforming, WGS, PrOx and/or methanation ones [3-6]. The water gas shift reaction $\left(\mathrm{CO}+\mathrm{H}_{2} \mathrm{O} \leftrightarrow \mathrm{CO}_{2}+\right.$ $\mathrm{H}_{2}$ ) is a critical step in fuel processors for preliminary $\mathrm{CO}$ clean-up and additional hydrogen generation prior to the $\mathrm{CO}$ preferential oxidation or methanation step [4-7]. WGS units are placed downstream of the reformer to lower the $\mathrm{CO}$ content and improve the $\mathrm{H}_{2}$ yield. However WGS is an equilibrium-limited reaction and $\mathrm{CO}$ concentrations below $10 \mathrm{ppm}$ (requisite for the PEMFC anode) cannot be reached even with high $\mathrm{H}_{2} \mathrm{O} / \mathrm{CO}$ ratios at reaction temperatures above $200{ }^{\circ} \mathrm{C}[8]$. Therefore, an additional $\mathrm{CO}$ removal process is always required.

Preferential $\mathrm{CO}$ oxidation of the pre-cleaned reformate stream (PrOx) with air is one of the most effective methods for $\mathrm{CO}$ abatement from the reformate stream prior to its introduction in the PEM cell [9]. High CO oxidation activities coupled with low hydrogen ones (at the desired oxidation temperature) are essential requirements for the PrOx catalysts $[10,11]$. 
In recent years, there has been great interest in the $\mathrm{CO}$ oxidation reaction over gold-based catalysts [12-14]. Despite bulk metallic gold being a very poor catalyst in this reaction, supported gold nanoparticles are able to eliminate $\mathrm{CO}$ even at sub-ambient temperatures $[15,16]$. Nanogold catalysts are promising candidates for the PrOx reaction for two main reasons: i) they show extraordinarily high activity in the low temperature range, which is appropriate for fuel cell applications, ii) the rate of $\mathrm{CO}$ oxidation exceeds that of hydrogen oxidation in the relevant temperature range $[17,18]$. In addition to high activity and selectivity, a suitable PrOx catalyst must also tolerate high amounts of $\mathrm{CO}_{2}$ and $\mathrm{H}_{2} \mathrm{O}$ present in the reformate stream [19]. Generally, the presence of both $\mathrm{CO}_{2}$ and $\mathrm{H}_{2} \mathrm{O}$ diminishes $\mathrm{CO}$ conversion, especially at low temperatures [20, 21]. An excellent WGS catalyst withstands high amount of $\mathrm{H}_{2} \mathrm{O}$. The ability of a catalyst to admit large ranges of $\mathrm{CO}_{2}$ concentrations in both WGS and PrOx, generally depends on its composition, specifically on the support nature, with acid supports more resistant to deactivation. It was recently reported by Tabakova et al. [2] that a $\mathrm{Au} / \mathrm{CeO}_{2}-\mathrm{Fe}_{2} \mathrm{O}_{3}$ system can successfully tolerate $\mathrm{CO}_{2}$ and $\mathrm{H}_{2} \mathrm{O}$ allowing good performance in the PrOx reaction. For the WGS reaction an efficient catalyst based on a similar system, $\mathrm{Au} / \mathrm{CeO}_{2}-\mathrm{FeO}_{\mathrm{x}} / \mathrm{Al}_{2} \mathrm{O}_{3}$ was also reported [22].

Following the concept of process intensification, it would be interesting to design a reactor where both reactions (PrOx and WGS) are successfully carried out in a single catalytic wall reactor by careful control of the temperature profile of the reactor and the reactant insertion zones, this way doing away with one reactor on the overall CO clean-up process (Scheme 1). The development of such an advanced reactor may reduce cost and system volume allowing the adaptation of this type of fuel processor to smaller devices for portable applications. Considering the experimental conditions in which WGS and PrOx take place, i.e. space velocity, temperature window, equilibrium limitations etc., coupling these reactions in a single reactor is a great 
challenge. Nevertheless, as a first step toward process intensification, the preparation of one efficient catalyst for both processes is required.

Considering the promising features of gold based systems for these reactions, the aim of this work is to study the possibilities of use of a gold-based WGS catalyst in the PrOx reaction with the idea of facilitating the possible future coupling of these reactions in a single reactor.

\section{Experimental}

\subsection{Catalyst preparation}

The supports were prepared by impregnation of $\mathrm{Ce}\left(\mathrm{NO}_{3}\right)_{3} \cdot 6 \mathrm{H}_{2} \mathrm{O}$ and $\mathrm{Fe}\left(\mathrm{NO}_{3}\right)_{3} \cdot 9 \mathrm{H}_{2} \mathrm{O}$ (Aldrich) on $\gamma$-alumina powder (Sasol) in order to obtain a cerium-iron mixed oxide dispersed on alumina. The precursor amounts were calculated in such a way so that the final loading of $\mathrm{CeO}_{2}$, $\mathrm{FeO}_{\mathrm{x}}$ or $\mathrm{CeO}_{2}-\mathrm{FeO}_{\mathrm{x}}$ solid solution were 15 wt. $\%$ of the final solid. In order to ensure the production of a $\mathrm{FeO}_{\mathrm{x}}-\mathrm{CeO}_{2}$ solid solution, the $\mathrm{FeO}_{\mathrm{x}}$ content was always maintained below $3 \mathrm{wt} \%$ [22]. Gold (2 wt.\% nominal) was deposited by the direct anionic exchange method, assisted by $\mathrm{NH}_{3}$, as described elsewhere [23].

In the adopted nomenclature, oxygen is omitted for simplification and the $\mathrm{FeO}_{\mathrm{x}}$ contents are expressed as the theoretical catalyst loading. For example, the $\mathrm{Au} / \mathrm{CeFe} 0.5 / \mathrm{Al}$ solid contains 2wt.\% Au loading over a $\mathrm{CeFe}$ mixed oxide in which the $\mathrm{FeO}_{\mathrm{x}}$ content is $0.5 \mathrm{wt} . \%$ and $\mathrm{CeO}_{2}$ loading is approximately $14.5 \mathrm{wt} . \%$, deposited on $\mathrm{Al}_{2} \mathrm{O}_{3}$ support. 


\subsection{Catalytic activity and selectivity}

\subsubsection{Preferential CO oxidation}

PrOx reaction was carried out at atmospheric pressure on a cylindrical fixed bed quartz reactor (9 mm inner diameter) at $60000 \mathrm{~cm}^{3} \mathrm{~g}_{\mathrm{cat}}{ }^{-1} \mathrm{~h}^{-1}$. For each test, $100 \mathrm{mg}$ of catalyst sieved between 100-200 $\mu \mathrm{m}$ were loaded in the reactor. To minimize, as far as possible, the thermal effects due to the oxidation reaction, the samples were diluted in quartz. The feed flow rate was $100 \mathrm{~cm}^{3} \min ^{-1}$ containing $1 \% \mathrm{CO}, 1.5 \% \mathrm{O}_{2}, 50 \% \mathrm{H}_{2}$ and $\mathrm{He}$ as a balance. To study the effect of $\mathrm{H}_{2} \mathrm{O}$ and $\mathrm{CO}_{2}$ on catalyst activity and selectivity, $10 \%$ of each compound was added in the feed. Prior to catalytic measurements, the samples were treated under a $100 \mathrm{~cm}^{3} \mathrm{~min}^{-1}$ flow of $21 \% \mathrm{O}_{2}$ in $\mathrm{He}$, at $300^{\circ} \mathrm{C}$ for $1 \mathrm{~h}$. The influence of the $\lambda$ parameter $\left(\lambda=2\left[\mathrm{O}_{2}\right] /[\mathrm{CO}]\right)$ was studied varying $\lambda$ from 1 to 4 conserving $1 \%$ of $\mathrm{CO}$ in all the cases. The influence of space velocity was studied by varying the WHSV between 12000 and $120000 \mathrm{~cm}^{3} \mathrm{~g}_{\text {cat }}{ }^{-1} \mathrm{~h}^{-1}$. Water was added to the dry gas stream via a HPLC pump (Gilson 307). Product and reactant analyses were carried out by a gas chromatograph (ShimadzuGC-14B) equipped with a TCD detector.

The CO conversion was calculated according to Eq. (1) where $\mathrm{CO}_{\text {in }}$ is the $\mathrm{CO}$ concentration in the inlet and $\mathrm{CO}_{\text {out }}$ is the one at the outlet:

$$
\text { CO conversion }(\%)=\frac{C O_{\text {in }}-\mathrm{CO}_{\text {out }}}{C O_{\text {in }}} \cdot 100
$$

The $\mathrm{O}_{2}$ selectivity towards $\mathrm{CO}_{2}$ formation was calculated with Eq. (2). $\mathrm{O}_{2 \text { in }}$ corresponds to oxygen in the inlet and $\mathrm{O}_{2 \text { out }}$ to the one at the outlet.

$$
\mathrm{O}_{2} \text { selectivity }(\%)=\frac{\left(\mathrm{CO}_{\text {in }}-\mathrm{CO}_{\text {out }}\right) \cdot 100}{2 \cdot\left(\mathrm{O}_{2 \text { in }-} \mathrm{O}_{2 \text { out }}\right)}
$$




\subsection{2. $\mathrm{CO}$ and $\mathrm{H}_{2}$ oxidation:}

$\mathrm{CO}$ and hydrogen oxidation were carried out at atmospheric pressure in a stainless steel fixed bed reactor $\left(9 \mathrm{~mm}\right.$ inner diameter) at 30000,60000 and $120000 \mathrm{~cm}^{3} \mathrm{gcat}^{-1} \mathrm{~h}^{-1}$. The composition of the $\mathrm{CO}$ oxidation stream was $1 \% \mathrm{CO}, 1.5 \% \mathrm{O}_{2}$ and $\mathrm{N}_{2}$ as balance, while for $\mathrm{H}_{2}$ oxidation the reactant stream was $1.5 \% \mathrm{O}_{2}, 50 \% \mathrm{H}_{2}$ balanced in $\mathrm{N}_{2}$. The catalyst $(100 \mathrm{mg}$, $100<\phi<200 \mu \mathrm{m})$ was diluted with crushed glass particles in the same particle size range forming a bed of about $5 \mathrm{~mm}$ in length. Products and reactants were analyzed by on-line gas chromatography (Agilent ${ }^{\circ}$ 6890) equipped with a HP PLOT Q and HP-5 columns and a TCD detector. Prior to catalytic measurements, the samples were treated under a $100 \mathrm{~cm}^{3} \mathrm{~min}^{-1}$ flow of $21 \% \mathrm{O}_{2}$ in $\mathrm{N}_{2}$, at $300^{\circ} \mathrm{C}$ for $1 \mathrm{~h}$.

\subsubsection{Water gas shift and Reverse water gas shift reactions}

The study of the water gas shift reaction was carried out at atmospheric pressure in a stainless steel fixed bed reactor $\left(7.5 \mathrm{~mm}\right.$ inner diameter) at $60000 \mathrm{~cm}^{3} \mathrm{~g}_{\mathrm{cat}}{ }^{-1} \mathrm{~h}^{-1}$. A $100 \mathrm{~cm}^{3} \mathrm{~min}^{-1}$ reaction mixture composed of $1 \% \mathrm{CO}, 10 \% \mathrm{H}_{2} \mathrm{O}$ and $\mathrm{N}_{2}$ as balance was flowed over $100 \mathrm{mg}$ of catalyst. For the reverse water gas shift, the reaction flow was composed of $10 \% \mathrm{CO}_{2}, 50 \% \mathrm{H}_{2}$ and $\mathrm{N}_{2}$ as balance and the same space velocity was used. Products and reactants were analyzed by on-line URAS $2 \mathrm{G} \mathrm{CO}, \mathrm{CO}_{2}$ gas analyzers (ABB A02020)

\subsection{4. $\mathrm{CO} / \mathrm{H}_{2}$ and $\mathrm{CO} / \mathrm{O}_{2} / \mathrm{CO}_{2} / \mathrm{CO}$ pulses}

For pulse experiments $100 \mathrm{mg}$ of catalyst was loaded into a U-shaped quartz reactor. The samples were first activated in an $\mathrm{O}_{2} / \mathrm{He}$ flow $\left(50 \mathrm{~cm}^{3} \mathrm{~min}^{-1}\right)$ at $300{ }^{\circ} \mathrm{C}$ during $1 \mathrm{~h}$. After cooling 
and stabilizing the temperature, $10 \mathrm{O}_{2}$ pulses followed by $10 \mathrm{H}_{2}$ pulses $\left(1 \mathrm{~cm}^{3}\right.$ each) were sent in order to reproduce as far as possible the PrOx reaction conditions. After that, $\mathrm{CO}-\mathrm{H}_{2}$ pulses were alternatively introduced in the reactor every $2 \mathrm{~min}$. The gas composition at the exit of the reactor was analyzed by a mass spectrometer PFEIFFER Vacuum Prisma Plus controlled by the program Quadera $^{\circledR}$.

To study the inhibitory effect of $\mathrm{CO}_{2}$, a series of $\mathrm{CO} / \mathrm{O}_{2} / \mathrm{CO}_{2} / \mathrm{CO}$ pulses were also studied. The sample was pretreated at $300{ }^{\circ} \mathrm{C}$ as explained above. Afterwards, the sample was cooled and the temperature was fixed at $150{ }^{\circ} \mathrm{C}$. $\mathrm{CO} / \mathrm{O}_{2} / \mathrm{CO}_{2} / \mathrm{CO}$ pulses $\left(1 \mathrm{~cm}^{3}\right.$ each) were sent and the gas composition at the exit of the reactor was analyzed with the same mass spectrometer.

\section{Results and discussion}

\subsection{Effect of iron in the PrOx reaction}

Full details of characterization and preparation of the studied catalysts have been given elsewhere [22]. Although, they are not subject of this study they will be further used for correlating the results obtained in the present work with the catalyst properties. Nevertheless, it is worth to briefly summarize the main results obtained in such previous work. In that study a high variation of WGS activity of $\mathrm{Au} / \mathrm{CeFeX} / \mathrm{Al}$ samples (with $\mathrm{X}$ varying from $0-3 \mathrm{wt} . \%$ ) with similar gold particle size was reported, depending on the extent of Ce-Fe interaction. The WGS activity is governed not only by the presence of gold and its particle size but also by the formation of a ceria-iron solid solution. The activity enhancement is related to a $\mathrm{Ce}-\mathrm{Fe}$ synergetic effect that favors water activation, either by the redox or associative mechanism. Deactivation of gold 
catalysts was observed and was attributed principally to the formation of carbonate and formate species, identified by Diffuse Reflectance Infrared Spectroscopy (DRIFT), which limit the accessibility of the support active sites for the activation of water.

The use of the same series of catalysts in the preferential CO oxidation leads to the activity and selectivity results presented in Figures $1 \mathrm{~A}$ and 1B, respectively. All catalysts are very active at low temperature. In general, a decrease in $\mathrm{CO}$ conversion is observed with increase of temperature, due to the increase of the hydrogen oxidation rate. As in WGS, the PrOx activity seems to be influenced by the catalyst composition, more precisely by the nature of the support. The $\mathrm{Au} / \mathrm{Al}_{2} \mathrm{O}_{3}$ catalyst was the least active followed by $\mathrm{Au} / \mathrm{Fe} / \mathrm{Al}$. On the other hand, $\mathrm{Au} / \mathrm{Ce} / \mathrm{Al}$ showed high activity for the preferential CO oxidation. This result points to the need of an active support to obtain a good $\mathrm{CO}$ abatement performance. The role of an active support like ceria is double, firstly it supplies oxygen to the $\mathrm{CO}$ oxidation process and secondly, the structural defects of ceria namely oxygen vacancies, may act as oxygen activation sites leading to more reactive oxygen species that further react with $\mathrm{CO}$. The $\mathrm{Au} / \mathrm{Ce} / \mathrm{Al}$ catalytic properties are enhanced when iron is added to the catalyst. The promotion of iron to ceria is evidenced in terms of the activity improvement, especially at low temperatures. $\mathrm{Au} / \mathrm{CeFe} 2 / \mathrm{Al}$ is the most active system in the temperature range $90-120{ }^{\circ} \mathrm{C}$ where an efficient PrOx catalyst should operate for fuel cell applications. This sample achieved 92\% CO conversion and 40\% $\mathrm{O}_{2}$ selectivity at low temperature $\left(50{ }^{\circ} \mathrm{C}\right)$ and $80 \% \mathrm{CO}$ conversion with $33 \%$ of oxygen selectivity towards $\mathrm{CO}_{2}$ at 110 ${ }^{\circ} \mathrm{C}$. The same sample, $\mathrm{Au} / \mathrm{CeFe} 2 / \mathrm{Al}$, was also the most efficient catalyst within the examined series in the WGS reaction, showing high yield of hydrogen in the medium temperature WGS window $\left(160-350^{\circ} \mathrm{C}\right)$, attributed to the strongest $\mathrm{Ce}-\mathrm{Fe}$ interaction resulting in an enhancement of the number of oxygen vacancies and therefore promoted redox properties. Indeed, in a recent 
paper, it has been demonstrated that the oxygen storage complete capacity (OSCC) and the oxygen storage capacity (OSC) of gold catalysts supported on ceria are considerably promoted by the addition of iron [24]. The numbers of atomic oxygen layers that participate in the redox process is higher when iron is employed as a ceria dopant. The inclusion of iron in the ceria lattice alters the covalent character of $\mathrm{Ce}-\mathrm{O}$ bonds favoring oxygen mobility and leading to promising materials for $\mathrm{CO}$ oxidation.

Regarding selectivity, the trend is similar for all catalysts: the higher the temperature, the lower the selectivity towards $\mathrm{CO}$ oxidation pointing out that $\mathrm{H}_{2}$ oxidation starts already from low temperatures and becomes more important when the temperature is increased. Au/Al sample was the least selective within the series. This can be correlated again with the redox properties of the supports in the PrOx reaction. As can be seen in Figure 1B, all the ceria containing samples presented similar selectivity profiles while $\mathrm{Au} / \mathrm{Al}$ and $\mathrm{Au} / \mathrm{Fe} / \mathrm{Al}$ are slightly different. It seems that the activation of oxygen in the support, which is a key step in the CO oxidation process, determines the shape of the curve. This oxygen activation is enhanced in the ceria-based samples due to a higher amount of structural defects in the ceria lattice, especially when iron is incorporated thus modulating both activity and selectivity.

\subsection{Influence of $\mathrm{CO}_{2}$ and $\mathrm{H}_{2} \mathrm{O}$}

To study the effect of $\mathrm{CO}_{2}$ in the series of catalysts, 4 samples were selected: $\mathrm{Au} / \mathrm{Al}$ (binary system), $\mathrm{Au} / \mathrm{Ce} / \mathrm{Al}, \mathrm{Au} / \mathrm{Fe} / \mathrm{Al}$ (ternary systems) and $\mathrm{Au} / \mathrm{CeFe} 2 / \mathrm{Al}$ (quaternary system). The effect of $\mathrm{CO}_{2}$ on activity and selectivity is analyzed in Figures $2 \mathrm{~A}$ and $2 \mathrm{~B}$, respectively. The presence of $\mathrm{CO}_{2}$ in the gas mixture has a negative effect on both oxygen selectivity and $\mathrm{CO}$ 
conversion. The $\mathrm{Au} / \mathrm{Al}$ catalyst was the less sensitive in $\mathrm{CO}_{2}$ presence. Regarding the ternary systems, $\mathrm{CO}_{2}$ affects more dramatically $\mathrm{Au} / \mathrm{Ce} / \mathrm{Al}$ than $\mathrm{Au} / \mathrm{Fe} / \mathrm{Al}$ in the temperature range 90$120^{\circ} \mathrm{C}$. Moreover, the negative effect of $\mathrm{CO}_{2}$ in $\mathrm{Ce}$ and $\mathrm{Fe}$ systems seems to be an additive effect since the quaternary $\mathrm{Au} / \mathrm{CeFe} 2 / \mathrm{Al}$ system is the most affected by the presence of $\mathrm{CO}_{2}$. As discussed in previous reports [25-27] the detrimental effect of $\mathrm{CO}_{2}$ may be due to the competitive adsorption of $\mathrm{CO}\left(\right.$ or $\left.\mathrm{H}_{2}\right)$ and $\mathrm{CO}_{2}$ on the catalyst surface. The nature of the support is thought to affect the catalyst behavior in the presence of $\mathrm{CO}_{2}$; acidic supports seem to be more resistant to deactivation than basic ones [28]. Generally, the intrinsic acid-base properties of ceria containing materials depend on the oxidation state of the cerium cations, with $\mathrm{Ce}^{3+}$ being a weaker acid than $\mathrm{Ce}^{4+}$. Considering the highly reducing atmosphere of the PrOx reaction, the presence of $\mathrm{Ce}^{3+}$ species is expected. Actually XANES data revealed that ceria evolves from $\mathrm{Ce}^{4+}$ to $\mathrm{Ce}^{3+}$ during the WGS reaction, which involves also a reducing atmosphere [29]. These reduced cerium species may give rise to the formation of stable carbonates (according to Pearson acidity [30] the interaction between $\mathrm{Ce}^{3+}$, a soft acid and $\mathrm{CO}_{3}{ }^{2-}$, a soft base would produce a stable covalent bond) and this can be the reason of the strong inhibition of the $\mathrm{CO}$ conversion caused by $\mathrm{CO}_{2}$. As for the iron promoted ceria sample, not only cerium carbonates but also iron ones $\left(\mathrm{FeCO}_{3}\right)$ should be considered. These species may block anionic sites on the support where oxygen adsorption occurs [31].

The influence of water was studied in the most active catalyst (Figure 3A and 3B). The addition of water involved a decrease on activity (Figure 3A) and selectivity (Figure 3B). The curves show that the detrimental effect of water is not as strong as the one observed by $\mathrm{CO}_{2}$. As was proposed for $\mathrm{CO}_{2}$, water could manifest a competitive adsorption behavior with $\mathrm{CO}$ for the active sites. In addition, the possible competition of water with oxygen for the electron-rich sites 
in the support where oxygen activation takes place should not be disregarded. This effect could also account for the decrease on the catalytic activity when water is included in the reaction mixture. In principle, the presence of water could generate via WGS reaction a beneficial effect in terms of $\mathrm{CO}$ abatement [32], although it also implies an additional hydrogen production, which competes with $\mathrm{CO}$ for the oxygen in the stream. Irrespectively the competitor molecule $\left(\mathrm{CO}_{2}, \mathrm{H}_{2} \mathrm{O}\right.$ or $\left.\mathrm{H}_{2}\right) \mathrm{CO}$ adsorption sites will be less available and $\mathrm{CO}$ oxidation activity necessarily decreases. The simulation of a real reformate stream with the inclusion of both $\mathrm{H}_{2} \mathrm{O}$ and $\mathrm{CO}_{2}$ in the input stream was also evaluated (Figure $3 \mathrm{~A}$ and $3 \mathrm{~B}$ ). The catalytic performance is highly affected by the presence of these two species, leading to a drop of almost $40 \%$ in CO conversion at $100{ }^{\circ} \mathrm{C}$. The negative effect of $\mathrm{CO}_{2}$ and $\mathrm{H}_{2} \mathrm{O}$ seems to be cumulative. The decrease in both activity and selectivity of the PrOx catalysts, due to the competitive adsorption of CO, $\mathrm{CO}_{2}$ and $\mathrm{H}_{2} \mathrm{O}$ on the catalyst surface has been broadly reported [33-36]. Again a decrease on the $\mathrm{O}_{2}$ activation rate due to the competition of oxygen with water and carbon dioxide should be considered. However, it seems that the deactivation is not attributed to any physicochemical modification of the catalysts, since the activity is fully recovered by switching to a $\mathrm{H}_{2} \mathrm{O}-\mathrm{CO}_{2}$ free atmosphere. Therefore the activity inhibition observed in a real reformate stream is not irreversible. From the later it be can deduced that the formation of carbonates species is not the only factor that explains the loss of activity. Lee et al. [37], demonstrated for a $\mathrm{CuOx} / \mathrm{CeO}_{2}$ model catalyst that the rate of the $\mathrm{CO}$ and $\mathrm{H}_{2}$ oxidation reactions depends on the partial pressure of $\mathrm{CO}_{2}$ and $\mathrm{H}_{2} \mathrm{O}$ resulting in negative reaction orders with respect to these compounds which agrees with our results. 


\subsection{Carbon monoxide and hydrogen oxidation}

Deeper insights of the $\mathrm{CO}$ and $\mathrm{H}_{2}$ oxidation competition could be obtained if both processes are studied separately. Figure 4 and Figure 5 summarize the data obtained when these two oxidation processes are carried out individually. Because of the large error in the quantification of water and the small change in hydrogen concentration due to the large excess of this compound, oxygen conversion has been selected for the comparative study of $\mathrm{H}_{2}$ combustion activity. Figure 4A presents the oxygen conversion during hydrogen combustion at different space velocities. The curves show that hydrogen oxidation starts from the very beginning at low temperatures and total oxygen consumption was achieved in all cases. It was observed that the hydrogen oxidation activity decreases when the space velocity is increased. Full oxygen conversion (or in other words, maximum hydrogen combustion) was reached at $110{ }^{\circ} \mathrm{C}$ and $30000 \mathrm{~cm}^{3} \mathrm{~g}^{-1} \mathrm{~h}^{-1}$ while total oxidation of hydrogen at $120000 \mathrm{~cm}^{3} \mathrm{~g}^{-1} \mathrm{~h}^{-1}$ was achieved at slightly higher temperatures.

The catalytic behavior of the $\mathrm{Au} / \mathrm{CeFe} 2 / \mathrm{Al}$ in the $\mathrm{CO}$ oxidation reaction is presented in Figure 5 . Taking into account the oxygen and the carbon monoxide input (1.5\% and $1 \%$ respectively) the maximum expected $\mathrm{O}_{2}$ conversion is $33 \%$ when full $\mathrm{CO}$ conversion is obtained. The oxygen consumption increases with the contact time. The lower the space velocity, the higher the $\mathrm{O}_{2}$ conversion is at the same temperature (Figure 5A). Regarding $\mathrm{CO}$ abatement, the same tendency was observed, $\mathrm{CO}$ oxidation increases when the space velocity decreases. Full $\mathrm{CO}$ conversion has been reached in all the experiments at about $140{ }^{\circ} \mathrm{C}$ (Figure 5B). Comparing Figure 4A and $5 \mathrm{~A}$, very relevant information can be extracted regarding $\mathrm{CO}$ and $\mathrm{H}_{2}$ competition for the oxygen available in the stream. At $120000 \mathrm{~cm}^{3} \mathrm{~g}^{-1} \mathrm{~h}^{-1}$ and at low temperatures, for example $55^{\circ} \mathrm{C}, 25 \%$ of the introduced oxygen was consumed in CO oxidation (maximum possible value of $33 \%$, taking into account, that for lambda parameter of 3 only $1 / 3$ of the oxygen can be consumed for $\mathrm{CO}$ 
oxidation), which corresponds to almost $80 \%$ of selectivity towards $\mathrm{CO}$ oxidation. At the same time only $21 \%$ (maximum possible value of $100 \%$ ) of oxygen was consumed in hydrogen oxidation. The later reinforces the idea that the $\mathrm{CO}$ oxidation is favored at low temperatures but the rate of hydrogen oxidation increases with the temperature.

Another interesting point to comment is that $\mathrm{CO}$ oxidation at low temperatures seems to be favored by the presence of $\mathrm{H}_{2}$. As it can be observed, the $\mathrm{CO}$ oxidation activity in the $\mathrm{PrOx}$ reaction of this sample at $60{ }^{\circ} \mathrm{C}$ is about $90 \% \mathrm{CO}$ conversion (Figure 1A) while the $\mathrm{CO}$ conversion on the $\mathrm{CO}$ oxidation at the same temperature is $60 \%$ (Figure $5 \mathrm{~B}$ ). Generally, the $\mathrm{CO}$ oxidation rate decreases in the presence of hydrogen for gold-based systems $[38,39]$. The negative effect is normally attributed to the competitive adsorption of $\mathrm{CO}$ and $\mathrm{H}_{2}$ on the catalyst surface. However, Rossignol and co-workers observed a boosting effect in CO oxidation activity when $\mathrm{H}_{2}$ was introduced in the reaction mixture [40]. In their work, they point out that molecular oxygen can be transformed through reaction with hydrogen into active species e.g. hydrogen peroxy-like compounds capable of oxidizing CO. Recently, DFT studies have supported the beneficial effect of $\mathrm{H}_{2}$ on $\mathrm{CO}$ oxidation over gold containing systems [41]. In this study, they propose the formation of $\mathrm{OOH}$ species on the support due to the reaction of $\mathrm{O}_{2}$ with $\mathrm{H}$. The $\mathrm{OOH}$ species dissociates easily resulting in the formation of active oxygen for $\mathrm{CO}$ oxidation. The later correlates with our results, where $\mathrm{H}_{2}$ promotes the CO-PrOx activity in the low temperature range. In this context, a good PrOx catalyst has to be paradoxically also active in the $\mathrm{H}_{2}$ oxidation or at least in the $\mathrm{H}_{2}$ dissociation. $\mathrm{H}_{2}$ oxidation in the presence of water is also worth to consider (Figure 4B). We have tested the activity of the $\mathrm{Au} / \mathrm{CeFe} 2 / \mathrm{Al}$ sample in the hydrogen oxidation including water in the feed stream. As can be seen in Figure 4B, full conversion of oxygen was achieved in the whole studied temperature range regardless of the space velocity 
used. According to these results it can be established that the presence of $\mathrm{H}_{2} \mathrm{O}$ does not affect the $\mathrm{H}_{2}$ oxidation in the studied temperature range. Nevertheless the results obtained for the $\mathrm{CO}$ oxidation in the presence of steam (Figure 5C) revealed that the presence of $\mathrm{H}_{2} \mathrm{O}$ decreases the $\mathrm{CO}$ oxidation activity. Under dry conditions (Figure 5B) total CO conversion was obtained at $140{ }^{\circ} \mathrm{C}$ for all contact times studied, however the inclusion of water in the reactants mixtures remarkably shifts the activity window. Total $\mathrm{CO}$ conversion was achieved at $230{ }^{\circ} \mathrm{C}$ and 60000 $\mathrm{cm}^{3} \mathrm{~h}^{-1} \mathrm{~g}^{-1}$ while for higher space velocities this point was not reached. From these results it can be established that water does compete with $\mathrm{CO}$ and $\mathrm{O}_{2}$ or at least, blocks the $\mathrm{CO}$ adsorption sites in the catalyst surface decreasing the $\mathrm{CO}$ oxidation activity.

\subsection{Influence of WGS and RWGS}

All these data reveal that the addition of water to the $\mathrm{PrOx}$ stream (Figure 3) alters the $\mathrm{CO}$ oxidation activity. In order to elucidate the effect of the possible parallel reactions, the water gas shift and the reverse water gas shift (RWGS) reactions were examined under PrOx conditions (temperature window $110-230{ }^{\circ} \mathrm{C}$ and similar space velocity) using the $\mathrm{Au} / \mathrm{CeFe} 2 / \mathrm{Al}$ sample. As an excellent WGS catalyst, activity in these processes is expected in the $160-350{ }^{\circ} \mathrm{C}$ temperature range and indeed some activity for both reactions at temperatures below $150{ }^{\circ} \mathrm{C}$ was found. In the case of the WGS the catalyst reached $14 \%$ of CO conversion at $230{ }^{\circ} \mathrm{C}$, which is a high value taking into account the space velocity $\left(60000 \mathrm{~cm}^{3} \mathrm{~g} \mathrm{cat}^{-1} \mathrm{~h}^{-1}\right)$. As for the RWGS also some activity was detected with $4.1 \%$ of $\mathrm{CO}_{2}$ conversion at $230{ }^{\circ} \mathrm{C}$. According to these data both WGS and RWGS reactions are expected to contribute above $200^{\circ} \mathrm{C}$. 


\subsection{Pulse experiments}

Very interesting information concerning $\mathrm{H}_{2} / \mathrm{CO}$ competition was deduced from pulse experiments, which are summarized in Figure 6. In good agreement with the activity data, $\mathrm{CO}$ oxidation is favored at low temperatures. At $30^{\circ} \mathrm{C}$ (Figure 6A) every $\mathrm{CO}$ pulse is accompanied with a $\mathrm{CO}_{2}$ signal accounting for the oxidation of $\mathrm{CO}$. Hydrogen combustion was not observed at $30^{\circ} \mathrm{C}$. Nevertheless $\mathrm{H}_{2}$ oxidation could not be totally discarded since at this temperature the corresponding peak of water may not appear due to the possible adsorption of water in the catalyst surface. It seems that CO is preferentially adsorbed on the catalysts at this temperature and the inclusion of hydrogen does not displace it, being $\mathrm{CO}$ oxidation the reaction that will proceed. However, on increasing the temperature to 90 or $150{ }^{\circ} \mathrm{C}$ (Figures $6 \mathrm{~B}$ and $6 \mathrm{C}$ respectively) the competition of both molecules for adsorption on the catalyst increases provoking a noticeable loss of $\mathrm{CO}$ oxidation yield. $\mathrm{CO}$ is no longer able to remove $\mathrm{H}_{2}$ molecules from the catalyst surface. In fact, at these temperatures, after three $\mathrm{H}_{2} / \mathrm{CO}$ pulses, $\mathrm{CO}$ oxidation is almost negligible pointing that $\mathrm{H}_{2}$ adsorption prevails over $\mathrm{CO}$ adsorption influencing the selectivity of the process. These results correlate with the activity data presented in Figure 1A for this $\mathrm{Au} / \mathrm{CeFe} 2 / \mathrm{Al}$ sample, where a decreasing tendency on $\mathrm{CO}$ conversion was observed. The pulse experiments easily demonstrate that the selectivity towards $\mathrm{CO}$ oxidation necessarily diminishes with temperature due to the competitive $\mathrm{CO} / \mathrm{H}_{2}$ adsorption on the catalyst surface. It should be noted that these experiments have been carried out in the absence of oxygen and, therefore, $\mathrm{CO}$ and $\mathrm{H}_{2}$ oxidation took place with oxygen provided by the catalysts (most probably oxygen from the ceria lattice). Further important information regarding the inhibitory effect of $\mathrm{CO}_{2}$ is extracted from Figure $6 \mathrm{D}$. Here the sample was treated first with ten $\mathrm{O}_{2}$ pulses (not shown in the figure) and after that some $\mathrm{CO}$ pulses were sent. $\mathrm{CO}$ oxidation was observed by the 
formation of $\mathrm{CO}_{2}$ (circle 1 in the figure). Afterward, some $\mathrm{O}_{2}$ pulses were sent again to recover the original situation and subsequently two $\mathrm{CO}_{2}$ pulses were sent in order to saturate the catalyst surface. $\mathrm{CO}$ was flowed just after $\mathrm{CO}_{2}$ and the $\mathrm{CO}$ oxidation activity in terms of $\mathrm{CO}_{2}$ formation notoriously decreased (circle 2). The area of the $\mathrm{CO}_{2}$ peak produced in this situation was half the one obtained in situation 1 pointing that $\mathrm{CO}$ oxidation activity is two times higher when $\mathrm{CO}_{2}$ is not present. The later confirms the hypothesis that $\mathrm{CO}_{2}$ blocks the oxygen activation sites limiting the catalytic performance in the PrOx reaction in good agreement with the activity results discussed above.

\subsection{Effect of lambda and space velocity.}

Frequently, from the industrial point of view, selectivity is more important than activity. We have tried to improve the activity/selectivity balance by modulating the $\lambda$ parameter. The activity and selectivity data obtained for different $\lambda$ values are presented in Figures 7A and 7B respectively. $\mathrm{CO}$ conversion and $\mathrm{O}_{2}$ selectivity show opposite trends on changing $\lambda$. The higher the value of $\lambda$, the higher the $\mathrm{CO}$ conversion and lower the $\mathrm{O}_{2}$ selectivity is.

This behaviour evidences the high activity of gold for both $\mathrm{CO}$ and $\mathrm{H}_{2}$ oxidation that has been discussed above. For low lambda values, lower CO conversion was obtained but at high selectivity because the majority of the available oxygen reacts preferentially with $\mathrm{CO}$ than with $\mathrm{H}_{2}$ especially at low temperatures, as observed in the independent $\mathrm{CO}$ and $\mathrm{H}_{2}$ oxidation tests. For high lambda values, high activity for both $\mathrm{CO}$ and hydrogen oxidation was observed, thus decreasing the selectivity. It is worth to point out that the differences in selectivity when lambda is changed are more significant at low temperatures $\left(60-90^{\circ} \mathrm{C}\right)$, where the $\mathrm{CO}$ oxidation is favored. However when the temperature is increased, $\mathrm{H}_{2}$ oxidation becomes important even for 
low lambdas values. Finally it must be underlined that there are no differences in terms of CO conversion between $\lambda=3$ and $\lambda=4$ confirming that $\lambda=3$ is an optimum value.

The contact time is also a point to consider for improving the conversion/selectivity ratio. Figures $8 \mathrm{~A}$ and $8 \mathrm{~B}$ show the influence of space velocity on the conversion and selectivity of the selected $\mathrm{Au} / \mathrm{CeFe} 2 / \mathrm{Al}$ catalyst. The conversion and selectivity follow the same tendency, the higher the WHSV, the lower the conversion and selectivity. In other words, the conversion/selectivity balance can be improved by increasing the contact time between the reactive molecules and the catalyst. It should be noted that better selectivity values can be achieved at low temperatures with $30000 \mathrm{~cm}^{3} \mathrm{~g}^{-1} \mathrm{~h}^{-1}$ instead of $12000 \mathrm{~cm}^{3} \mathrm{~g}^{-1} \mathrm{~h}^{-1}$ suggesting that $30000 \mathrm{~cm}^{3} \mathrm{~g}^{-1} \mathrm{~h}^{-1}$ could be the optimum space velocity. However the higher $\mathrm{CO}$ conversion was obtained for the lowest space velocity. This observation is directly correlated with the tendency presented in the WGS reaction where the lower the space velocity, the higher the CO conversion $[22]$.

\subsection{Influence of $\mathrm{O}_{2} / \mathrm{CO}$ and the $\mathrm{H}_{2} \mathrm{O} / \mathrm{CO}_{2}$}

Finally, in an attempt of arriving at the best conversion/selectivity balance, the influence of the $\mathrm{O}_{2} / \mathrm{CO}$ (Figure 9A) and the $\mathrm{H}_{2} \mathrm{O} / \mathrm{CO}_{2}$ (Figure 9B) ratios in a simulated reforming stream at the optimum value of $30000 \mathrm{~cm}^{3} \mathrm{~g}^{-1} \mathrm{~h}^{-1} \mathrm{WHSV}$ and the temperature at $110^{\circ} \mathrm{C}$ was studied. Figure 9A suggests that the best conversion/selectivity balance in these realistic conditions is achieved for a $\lambda$ value of 2.5 whereas the CO conversion is $53 \%$ with an oxygen selectivity value of $27 \%$. Concerning $\mathrm{H}_{2} \mathrm{O} / \mathrm{CO}_{2}$, Figure 9B reveals that the $\mathrm{CO}$ conversion and the $\mathrm{O}_{2}$ selectivity increase with increase of this ratio. Taking into account that both $\mathrm{CO}_{2}$ and $\mathrm{H}_{2} \mathrm{O}$ inhibit the activity, $\mathrm{CO}_{2}$ being the strongest inhibitor, it seems that water mitigates the $\mathrm{CO}_{2}$ detrimental effect. Part of $\mathrm{CO}$ 
could be also consumed by the water gas shift reaction, enhancing the global $\mathrm{CO}$ oxidation activity.

\subsection{Influence of CO concentration}

To confirm this hypothesis, PrOx reaction in a realistic reforming stream using different amounts of $\mathrm{CO}$ in the inlet was evaluated and the results are presented in Figure 10. Very relevant information is extracted from the $\mathrm{CO}$ conversion trend in Figure 10A. The increase of the $\mathrm{CO}$ concentration, dramatically improves the $\mathrm{CO}$ conversion. For low carbon monoxide levels, 0.5 and $1 \mathrm{v} / \mathrm{v} \%$ (typical CO concentrations in the PrOx reactor inlet), the conversion is low and decreases with the temperature. Nevertheless, for higher CO levels (1.5 and $2 \mathrm{v} / \mathrm{v} \%)$, the conversion is remarkably superior and remains stable with temperature. In other words, when the reaction conditions approach those of the WGS reaction (high $\mathrm{CO}$ and $\mathrm{H}_{2} \mathrm{O}$ concentrations), $\mathrm{CO}$ oxidation is favored confirming that a part of $\mathrm{CO}$ abatement takes place via WGS due to the suitability of this $\mathrm{Au} / \mathrm{CeFe} 2 / \mathrm{Al}$ sample for the shift reaction. Similar beneficial effect was found for the selectivity values (Figure 10B). The increase of the $\mathrm{CO}$ amount in the feed is associated to the increase on the selectivity towards $\mathrm{CO}_{2}$ indicating that the competition among $\mathrm{CO}$ and $\mathrm{H}_{2}$ oxidation is sensitive to the amount of $\mathrm{CO}$ due to the WGS influence and the higher surface coverage of $\mathrm{CO}$ at high $\mathrm{CO}$ concentration in the feed. This is a very promising result considering the idea of coupling WGS and PrOx since, in the case of a not very successful WGS step, a high concentration of $\mathrm{CO}$ will be introduced in the PrOx unit and this catalyst tolerates large amounts of CO. 
From all the above, relevant information can be extracted in order to address the main issue of this work; could these efficient WGS catalysts be successfully used in the PrOx reaction? It is not that easy to find a definite answer. It has been demonstrated in this work that a gold catalyst supported on ceria-iron mixed oxide is very active in $\mathrm{CO}$ oxidation in the presence of $\mathrm{H}_{2}$ but its selectivity is limited especially in the high temperature range. In addition, the approach to a real reformate stream limits the $\mathrm{CO}$ oxidation activity of this system. It seems that this catalyst does not successfully tolerate the presence of $\mathrm{H}_{2} \mathrm{O}$ and $\mathrm{CO}_{2}$, especially $\mathrm{CO}_{2}$, but this detrimental effect could be mitigated with increase of the $\left[\mathrm{H}_{2} \mathrm{O} / \mathrm{CO}_{2}\right]$ ratio, which leads to an increase on the activity and selectivity. Moreover, a relevant point to consider is that this catalyst works more efficiently at high $\mathrm{CO}$ concentrations whereas $\mathrm{CO}$ evidently competes more favorably than hydrogen for the active sites. Overall, it can be concluded that $\mathrm{Au} / \mathrm{CeFe} 2 / \mathrm{Al}$ could effectively oxidizes $\mathrm{CO}$ in a $\mathrm{H}_{2}$-rich stream as long as the reaction would occur at the lowest temperature and space velocity possible, the highest $\mathrm{H}_{2} \mathrm{O} / \mathrm{CO}_{2}$ ratio, uppermost $\mathrm{CO}$ concentrations and a properly modulated $\lambda$ value. Under the mentioned reaction conditions the best activity/selectivity balance is obtained for this kind of catalysts.

\section{Conclusions}

The possible application of a highly effective WGS series of catalysts in the PrOx reaction for $\mathrm{H}_{2}$ clean up processes has been investigated. All the prepared solids are very efficient for $\mathrm{CO}$ oxidation in the presence of hydrogen especially at low temperatures in an ideal PrOx atmosphere $\left(\mathrm{CO}_{2}\right.$ and $\mathrm{H}_{2} \mathrm{O}$ free $)$. The inclusion of $\mathrm{CO}_{2}$ and $\mathrm{H}_{2} \mathrm{O}$ in the stream involves a loss of activity, with $\mathrm{CO}_{2}$ being the strongest inhibitor. 
The study of $\mathrm{CO}$ and $\mathrm{H}_{2}$ oxidation separately revealed that both molecules do compete for the oxygen in the stream. CO oxidation is favored at low temperatures, however these gold-based catalysts are able to oxidize also $\mathrm{H}_{2}$ at low temperatures. The ability of the samples to oxidize $\mathrm{H}_{2}$ limits the selectivity of the process. However, the presence of $\mathrm{H}_{2}$ increases the $\mathrm{CO}$ oxidation activity most probably due to the formation of additional reactive intermediates in the presence of hydrogen.

As a final remark, an excellent WGS catalyst like the $\mathrm{Au} / \mathrm{CeFe} 2 / \mathrm{Al}$ system could also be a promising catalyst for the PrOx reaction. Nevertheless, it has to be taken into account that the conditions of both processes (temperature window, space velocity, and amount of $\mathrm{H}_{2} \mathrm{O}, \mathrm{CO}, \mathrm{CO}_{2}$ and $\mathrm{H}_{2}$ ) are different and therefore, a careful modulation of the reaction parameters is required for a successful coupling of both reactions with the same catalyst. Even by modulating the reaction parameters, our systems are not able to satisfy the demanding requirements of fuel cells and further investigations are needed to achieve this goal with the same catalyst via WGS and PrOx. However this study provides some clues towards the future development of such a multirole catalyst. In particular with our catalysts, higher $\mathrm{CO}$ oxidation yields are achieved when the reaction conditions get closer to those of the WGS (higher amounts of CO and lower space velocities). Also the increase of the $\left[\mathrm{H}_{2} \mathrm{O}\right] /\left[\mathrm{CO}_{2}\right]$ ratio promotes both activity and selectivity. According to the promoted $\mathrm{CO}$ oxidation activity due to the influence of the WGS reaction the presented catalysts should be especially useful in CO-rich PrOx atmospheres. 


\section{Acknowledgements}

Financial support for this work has been obtained from the Spanish Ministerio de Ciencia e Innovación (ENE2012-374301-C03-01) co-financed by FEDER funds from the European Union and from Junta de Andalucía (TEP-8196). S. Ivanova and S. Palma acknowledge MEC for their Ramón y Cajal contract and pre-doctoral fellowship respectively. T.R. Reina acknowledges CSIC for his JAE-Predoc fellowship co-financed by the European social program and all the authors acknowledge Junta de Andalucía—“'TEP 106 group’. Sasol is gratefully acknowledged for supplying alumina samples.

\section{References}

[1] A. Biyikoglu, Int. J. Hydrogen Energy 30 (2005) 1181-1212.

[2] T. Tabakova, G. Avgouropoulos, J. Papavasiliou, M. Manzoli, F. Boccuzzi, K. Tenchev, F. Vindigini, T. Ioannides, Appl. Catal. B 101 (2011) 256-265.

[3] C. Song, Catal. Today 77 (2002), 17-49.

[4] G. Kolb, in "Fuel Processing for Fuel Cells" Ed. (G. Kolb), Wiley-VCH, Weinheim, 2008.

[5] O. Sanz, F.J Echave, F. Romero-Sarria, J.A. Odriozola, M. Montes in "Renewable Hydrogen Technologies", Eds. (L.M. Gandia, G. Arzamendi, P.M. Dieguez), Elsevier, Amsterdam 2013, p. 201.

[6]S. Ivanova, O.H. Laguna, M.A. Centeno, A. Eleta, M. Montes, J.A. Odriozola, in "Renewable Hydrogen Technologies", Eds (L.M. Gandia, G. Arzamendi, P.M. Dieguez,) Elsevier, Amsterdam 2013, p. 225.

[7] A.F. Ghenciu, Current opinion in Solid State and Material Science 6 (2002) 389-399.

[8] E.D. Park, D. Lee, H.C. Lee, Catal. Today 139 (2009) 280-290. 
[9] F. Mariño, G. Baronetti, M. Laborde, N. Bion, A. Le Valant, F. Epron, D. Duprez, Int. J. Hydrogen Energy 33 (2008)1345-1353.

[10] T.V. Choudhary, D.W. Goodman, Catal. Today 77 (2002) 65-78.

[11] T. Shodiya,O. Schmidt, W. Peng, N. Hozt, J. Catal. 300 (2013) 63-69.

[12] M. Haruta, S. Tsubota, T. Kobayashi, H. Kageyama, M.J. Genet, B. Delmon, J. Catal. 144 (1993) 175-192.

[13] M. Valden, X. Lai, D.W. Goodman, Science 281 (1998)1647-1650.

[14] K. Ruth, M. Hayes, R. Burch, S. Tsubota, M. Haruta, Appl. Catal. B 24 (2000)133-138.

[15] T.R. Reina, S. Ivanova, M.I. Domínguez, M.A. Centeno, J.A. Odriozola, Appl. Catal. A 419-420 (2012) 58-66.

[16] T.R. Reina, A. Álvarez, S. Ivanova, J. A. Odriozola, M. A. Centeno, ChemCatChem 4 (2012) 512-520.

[17] R.J.H. Grisel, C.J. Weststrate, A. Goossens, M.W.J. Crajé, A.M. van der Kraan, B.E. Nieuwenhuys, Catal. Today 72 (2002) 123-132.

[18] R.H. Torres Sanchez, A. Ueda, K. Tanaka, M. Haruta, J. Catal. (168) 1997 125-127.

[19] G. Avgouropoulos, M. Manzoli, F. Boccuzzi, T. Tabakova, J. Papavasiliou, T. Ioannides, V. Idakiev, J. Catal. 256 (2008) 237-247.

[20] O.H. Laguna, E.M. Ngassa, S. Oraa, A. Alvarez, M.I. Dominguez, F. Romero-Sarria, G. Arzamendi, L.M. Gandia, M.A. Centeno, J.A. Odriozola, Catal. Today 180 (2012) 105-110. [21] G. Avgouropoulos, J. Papavasiliou, T. Tabakova, V. Idakiev, T. Ioannides, Chem. Eng. J. 124 (2006) 41-45.

[22] T.R. Reina, S. Ivanova, V. Idakiev, J.J. Delgado, I. Ivanov, T. Tabakova, M.A. Centeno, J.A. Odriozola, Catal. Sci. Technol. 3 (3) (2013) 779-787. 
[23]S. Ivanova, C. Petit, V. Pitchon, Appl. Catal. A 267 (2004) 191-201.

[24] T.R. Reina, S. Ivanova, M.A. Centeno, J.A. Odriozola, Frontries in Chemistry 1 (2013) 12.

[25] W.Y. Hernández, M.A. Centeno, F.Romero-Sarria, S.Ivanova, M.Montes, J.A. Odriozola, Catal. Today 157 (2010) 160-165.

[26] J.W. Park, J.H. Jeong, W.L. Yoon, C.S. Kim, D.K. Lee, Y. Park, Y.W. Rhee, Int. J. Hydrogen Energy 30 (2005) 209-220.

[27] P. Naknam, A. Luengnaruemitchai, S. Wongkasemjit, Energy Fuels 23 (2009) 5084-5091.

[28] G.C. Bond, D.T. Thompson, Catal. Rev.Sci. Eng. 41 (1999) 319-388.

[29] T. R. Reina, W. Xu, S. Ivanova, M. A. Centeno, J. Hanson, J. A. Rodriguez, J.A.

Odriozola, Catal. Today 205 (2013) 41-48.

[30] R.G. Parr, R. G. Pearson, J. Am. Chem. Soc. 105 (1983) 7512-7516.

[31] G. Arzamendi, I. Uriz, P.M. Diéguez, O.H. Laguna, W.Y. Hernández, A. Álvarez, M.A. Centeno, J.A. Odriozola, M. Montes, L.M. Gandía, Chem. Eng. J. 167 (2011) 588-596.

[32] F. Romero-Sarria,A. Penkova, L.M. Martinez, M.A. Centeno, K. Hadjiivanov, J.A. Odriozola, Appl. Catal. B 84 (2008) 119-124.

[33] G. Avgouropoulos, T. Ioannides, Appl. Catal. A 244 (2003) 155-167.

[34] P. Snytnikov, V. Sobyanin, V. Belyaev, P. Tsyrulnikov, N. Shitova, D.Shlyapin, Appl. Catal. A 239 (2003) 149-156.

[35] A. Luengnaruemitchai, S. Osuwan, E. Gulari, Int. J. Hydrogen Energy 29 (2004) 429-435.

[36] A. Luengnaruemitchai, D.T. Kim Thoa, S. Osuwan, E. Gulari, Int. J. Hydrogen Energy 30 (2005) 981-987.

[37] H.C. Lee, D.H. Kim, Catal. Today 132 (2008) 109-116.

[38] R.J.H. Grisel, B.E. Nieuwenhuys, J. Catal. 199 (2001) 48. 
[39] B. Schumacher, Y. Denkwitz, V. Plzak, M. Kinne, R.J. Behm, J. Catal. 224 (2004) 449.

[40] C. Rossignol, S. Arrii, F. Morfin, L. Piccolo, V. Caps, J.L. Rousset, J. Catal. 230 (2005) $476-483$.

[41] A. Hussain, J. Gracia, J.W. Niemantsverdriet, B.E. Nieuwenhuys, Molecules 16 (2011) 9582-9599.

Scheme 1: $\mathrm{H}_{2}$ clean-up process via WGS-PROX reactions.

Figure 1 Catalytic PROX screening; A) CO conversion; B) $\mathrm{O}_{2}$ Selectivity.

Figure 2 Influence of $\mathrm{CO}_{2}$ in the PROX stream; A) CO conversion; B) $\mathrm{O}_{2}$ Selectivity. Reaction mixture: $1 \% \mathrm{CO} ; 1.5 \% \mathrm{O}_{2} ; 50 \% \mathrm{H}_{2} ; 10 \% \mathrm{CO}_{2}$ balanced in $\mathrm{N}_{2}$

Figure 3 Influence of water and $\mathrm{CO}_{2}$ in the PROX behavior of the most active catalyst. A) $\mathrm{CO}$ conversion; B) $\mathrm{O}_{2}$ Selectivity.

Figure $4 \mathrm{H}_{2}$ oxidation test of the most active catalyst A) dry conditions (gas mixture: $1.5 \% \mathrm{O}_{2} ; 50 \% \mathrm{H}_{2}$ balanced in $\mathrm{N}_{2}$ ) B) $\mathrm{H}_{2}$ oxidation in the presence of water (gas mixture: $1.5 \% \mathrm{O}_{2} ; 10 \% \mathrm{H}_{2} \mathrm{O}, 50 \% \mathrm{H}_{2}$ balanced in $\mathrm{N}_{2}$ ).

Figure $5 \mathrm{CO}$ oxidation test of the most active catalyst A) $\mathrm{O}_{2}$ conversion in dry conditions (gas mixture: $1.5 \% \mathrm{O}_{2} ; 1 \% \mathrm{CO}$ balanced in $\mathrm{N}_{2}$ ) B) CO conversion in dry conditions (gas mixture: $1.5 \% \mathrm{O}_{2} ; 1 \% \mathrm{CO}$ balanced in $\mathrm{N}_{2}$ ) C) CO conversion under steam (gas mixture: $1.5 \% \mathrm{O}_{2} ; 1 \% \mathrm{CO} 10 \% \mathrm{H}_{2} \mathrm{O}$ balanced in $\mathrm{N}_{2}$ ) Figure $6 \mathrm{CO} / \mathrm{H}_{2}$ pulses experiment. A) Sequence of $\mathrm{CO}$ (red lines) $/ \mathrm{H}_{2}$ (black lines) pulses at $30^{\circ} \mathrm{C}$; B) Sequence of $\mathrm{CO} / \mathrm{H}_{2}$ pulses at $90^{\circ} \mathrm{C}$; C) Sequence of $\mathrm{CO} / \mathrm{H}_{2}$ pulses at $150^{\circ} \mathrm{C}$. D) Effect of $\mathrm{CO}_{2}$. For all the cases $\mathrm{CO}$ and $\mathrm{H}_{2}$ oxidation are followed by the apparition of $\mathrm{CO}_{2}$ (olive line) and $\mathrm{H}_{2} \mathrm{O}$ (magenta line) signals.

Figure 7 Effect of $\lambda$ parameter in the A) Activity and B) Selectivity of the most active catalyst. Experiments carried out at $60000 \mathrm{~cm}^{3} \mathrm{~g}^{-1} \mathrm{~h}^{-1}$ and in the absence of $\mathrm{H}_{2} \mathrm{O}$ and $\mathrm{CO}_{2}$ in the stream. 
Figure 8 Effect of WHSV in the A) Activity and B) Selectivity of the most active catalyst. Experiments carried out at $\lambda=3$ and in the absence of $\mathrm{H}_{2} \mathrm{O}$ and $\mathrm{CO}_{2}$ in the stream.

Figure 9 Influence of the $\mathrm{O}_{2} / \mathrm{CO}$ A) and $\mathrm{H}_{2} \mathrm{O} / \mathrm{CO}_{2}$ B) ratios in a simulated reforming stream at selected WHSV and temperature.

Figure 10 Influence of $\mathrm{CO}$ concentration (at $\lambda=3$ and $60000 \mathrm{~cm}^{3} \mathrm{~g}^{-1} \mathrm{~h}^{-1}$ ) A) $\mathrm{CO}$ conversion; B) $\mathrm{O}_{2}$ Selectivity. Experiments carried out in the presence of $10 \%$ of $\mathrm{CO}_{2}$ and $10 \%$ of $\mathrm{H}_{2} \mathrm{O}$.

\section{Scheme 1}

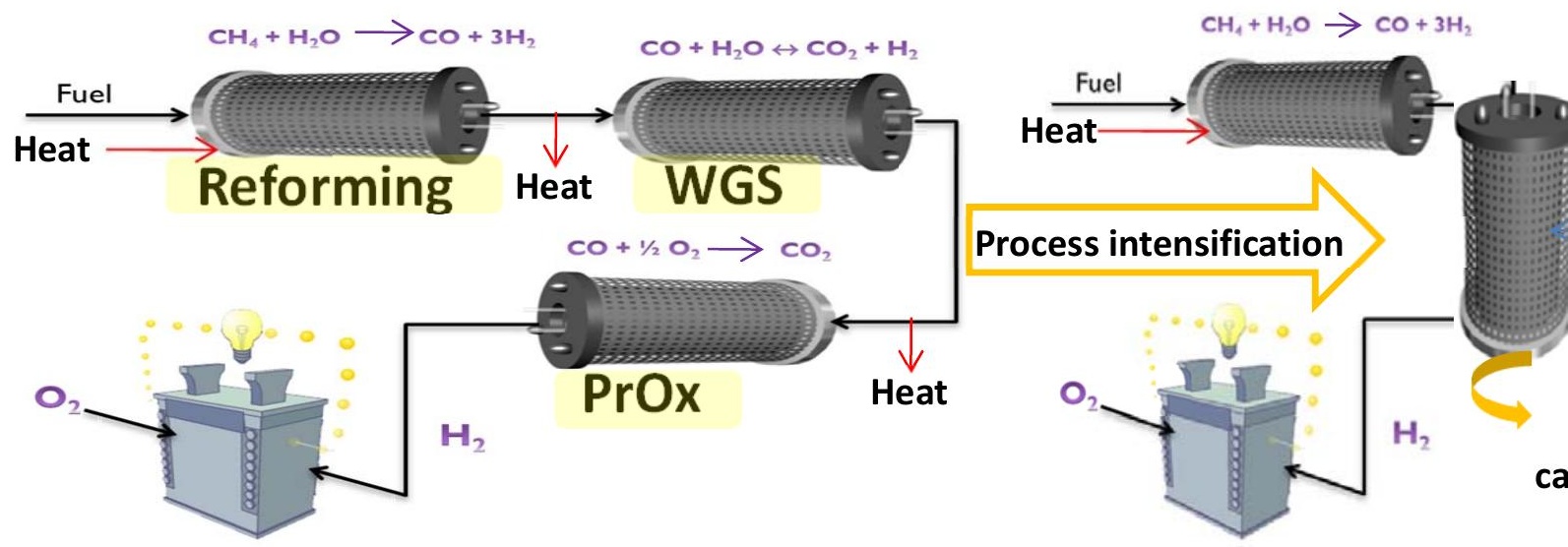




\section{Figure 1}
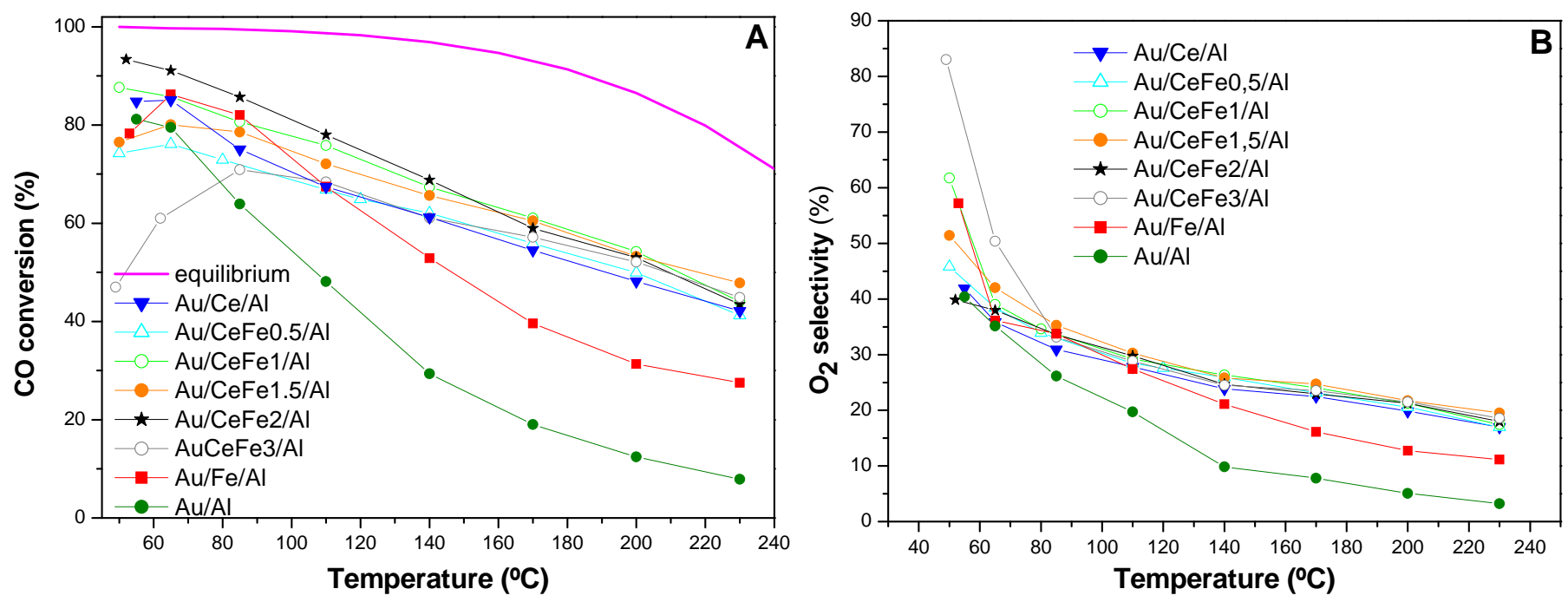
Figure 2
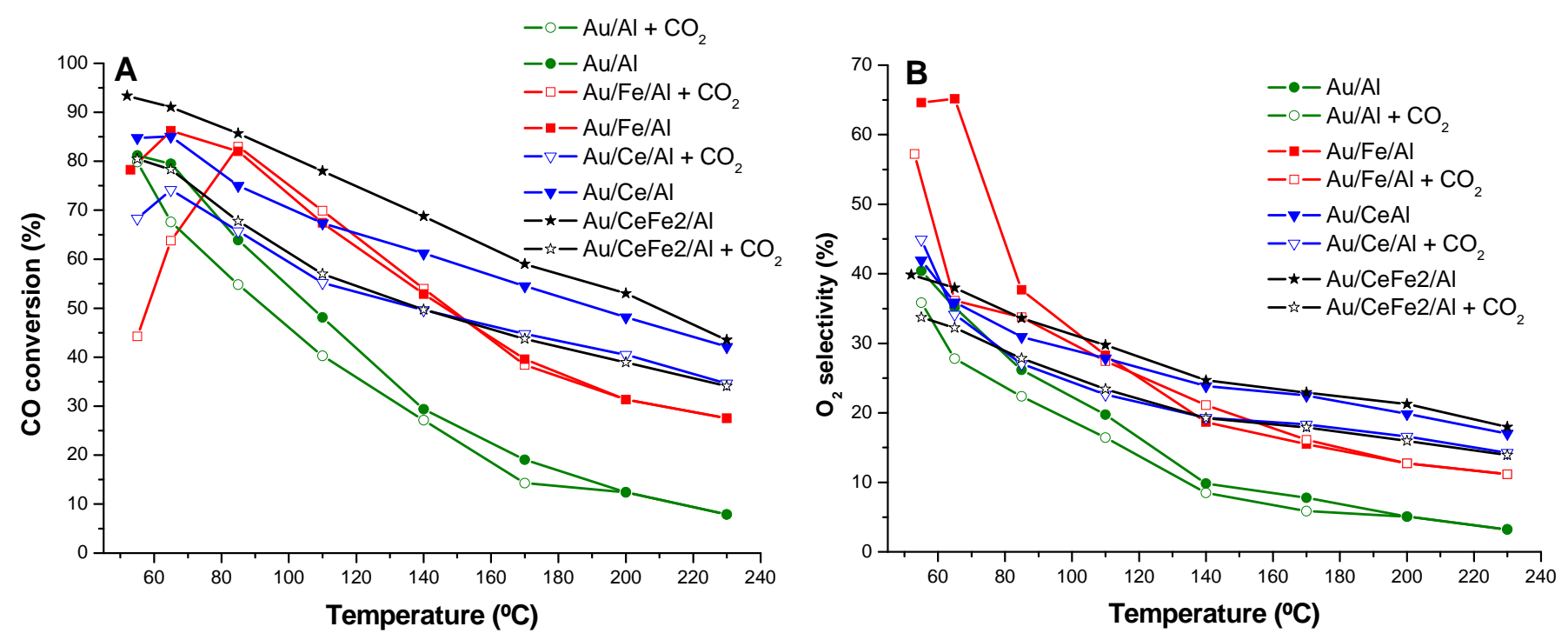


\section{Figure3}
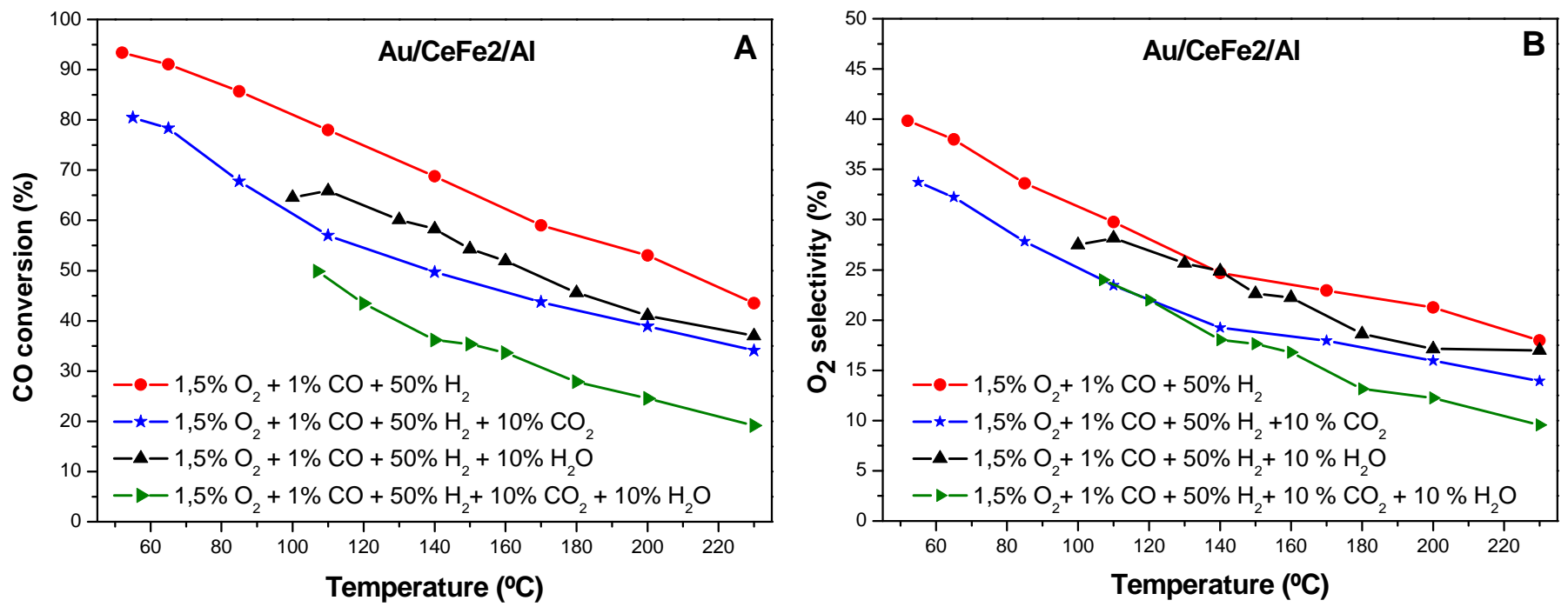


\section{Figure 4}
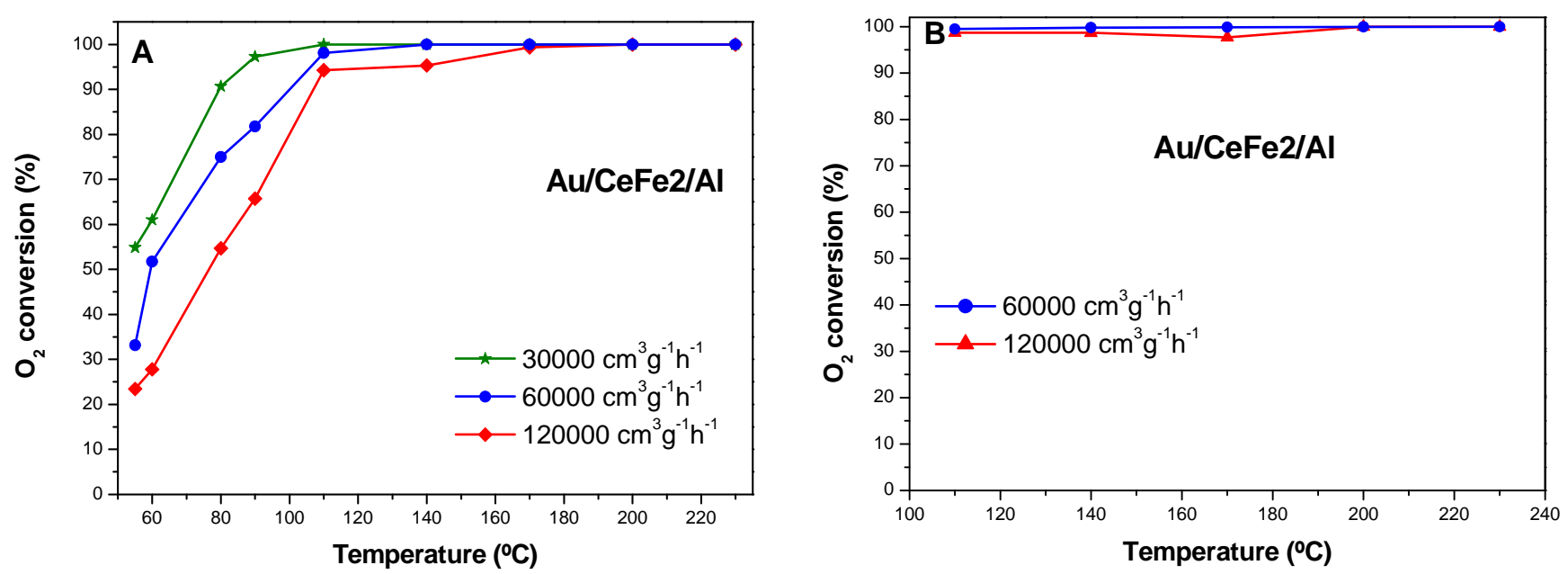
Figure 5
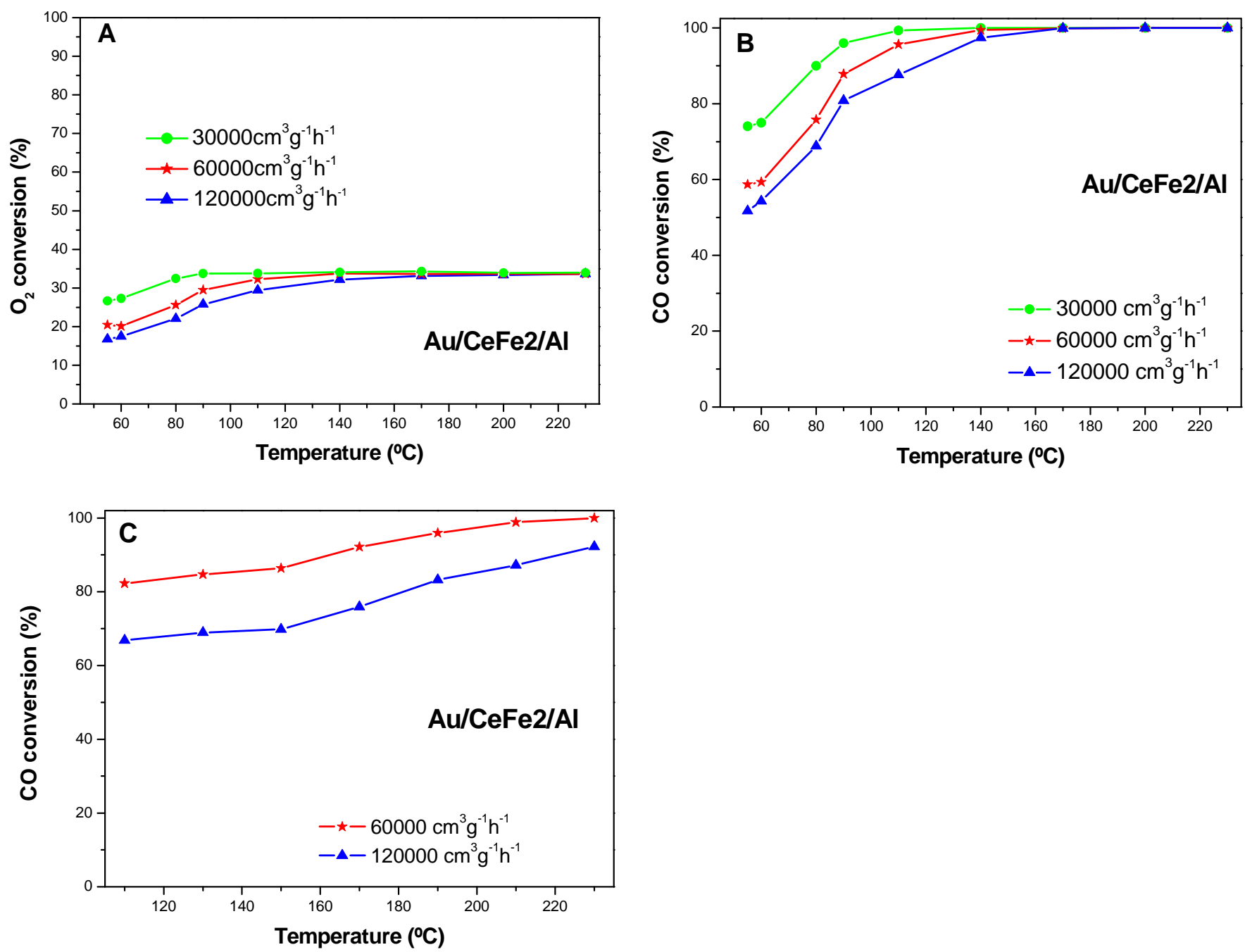
Figure 6
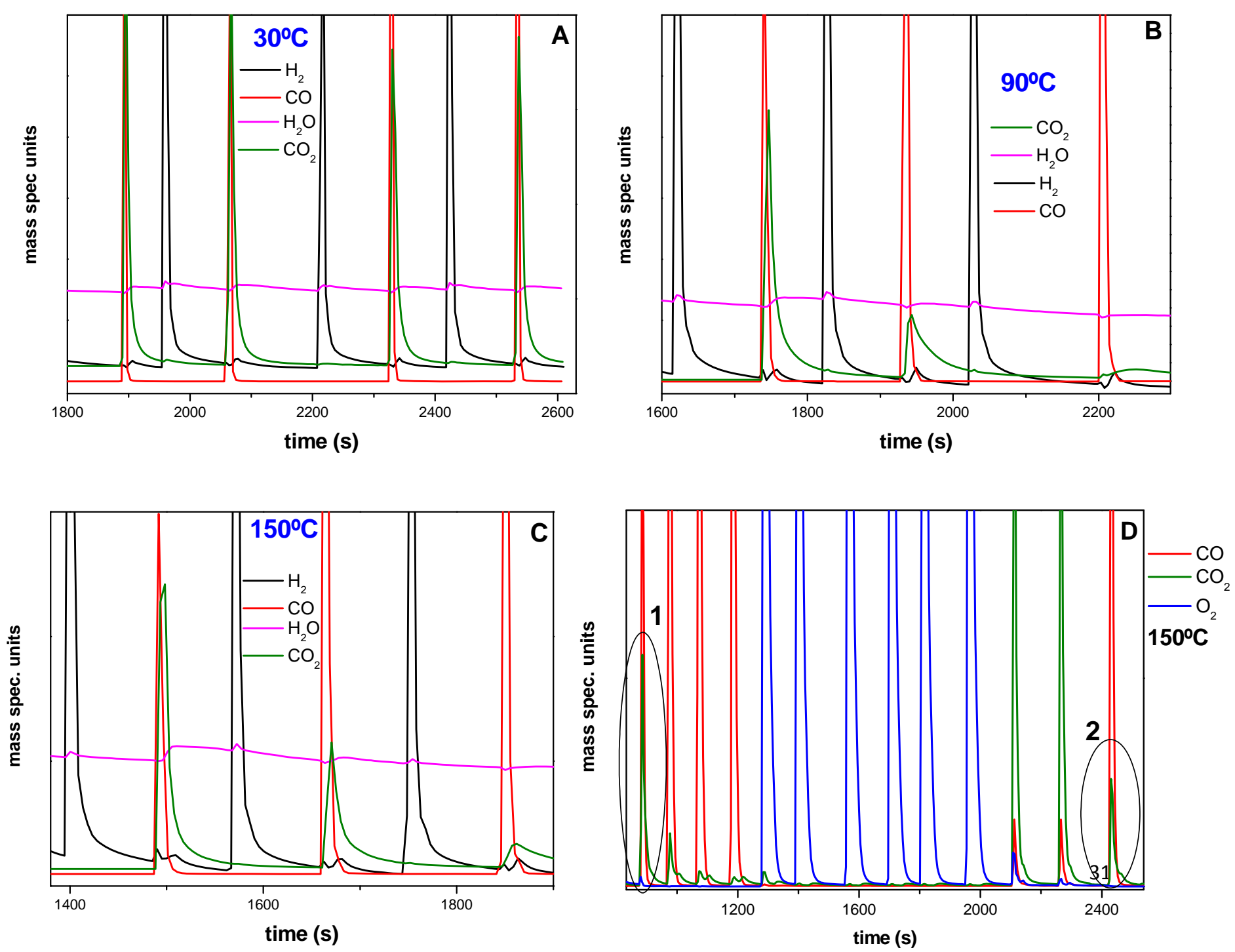
Figure 7
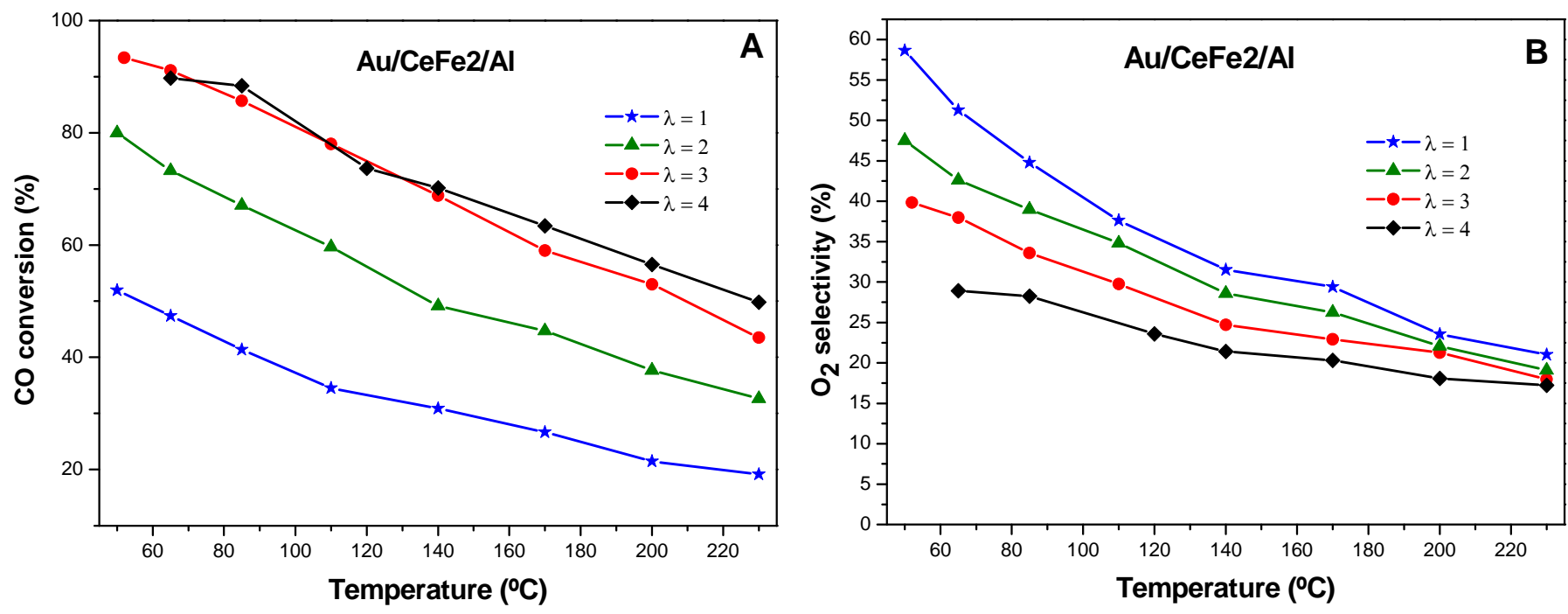
Figure 8
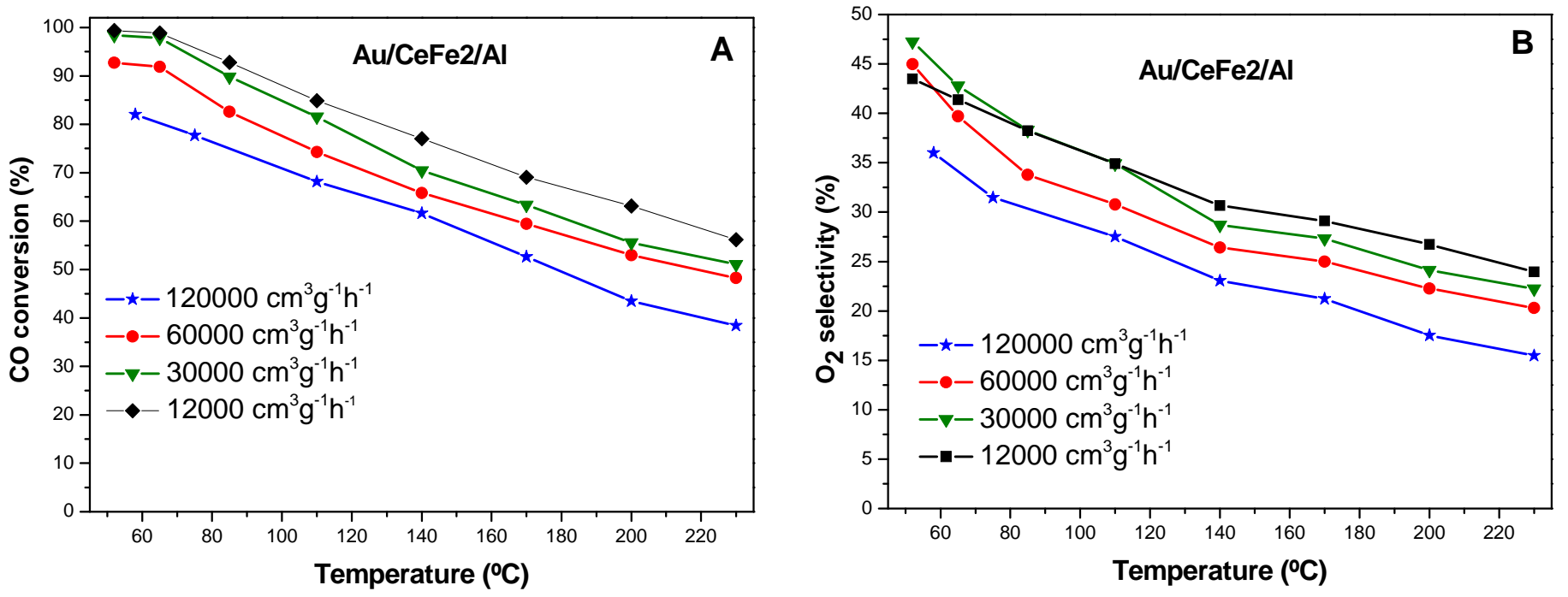


\section{Figure 9}
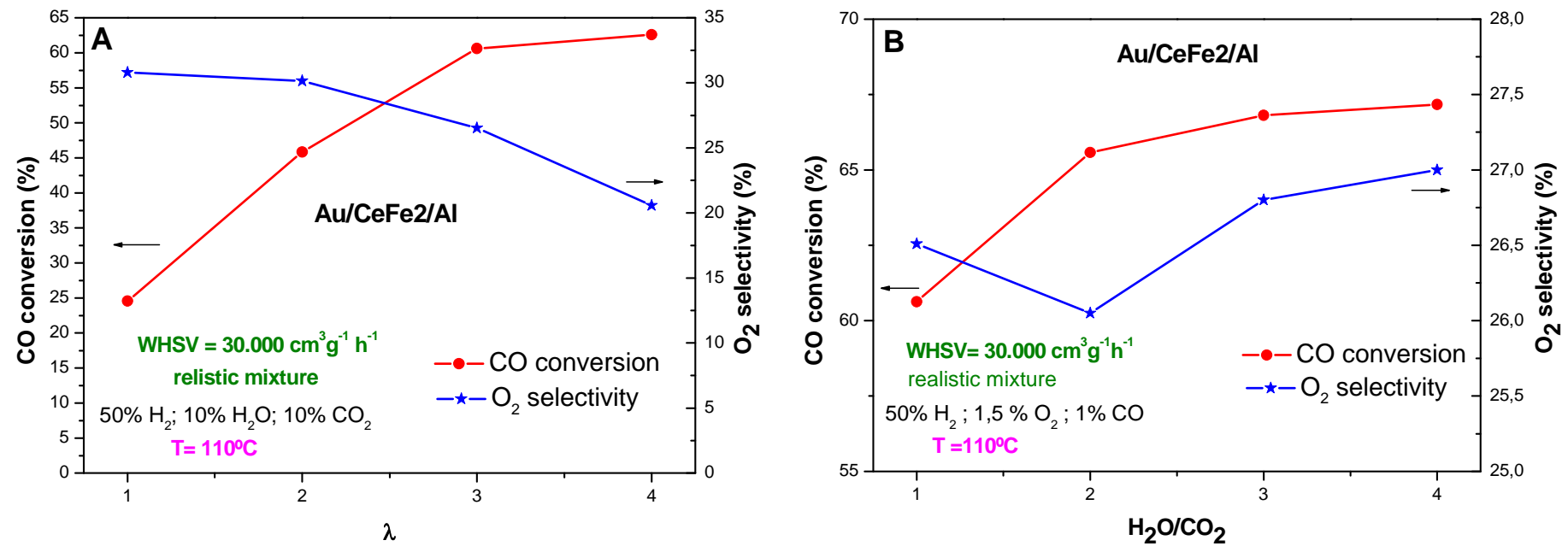
Figure 10
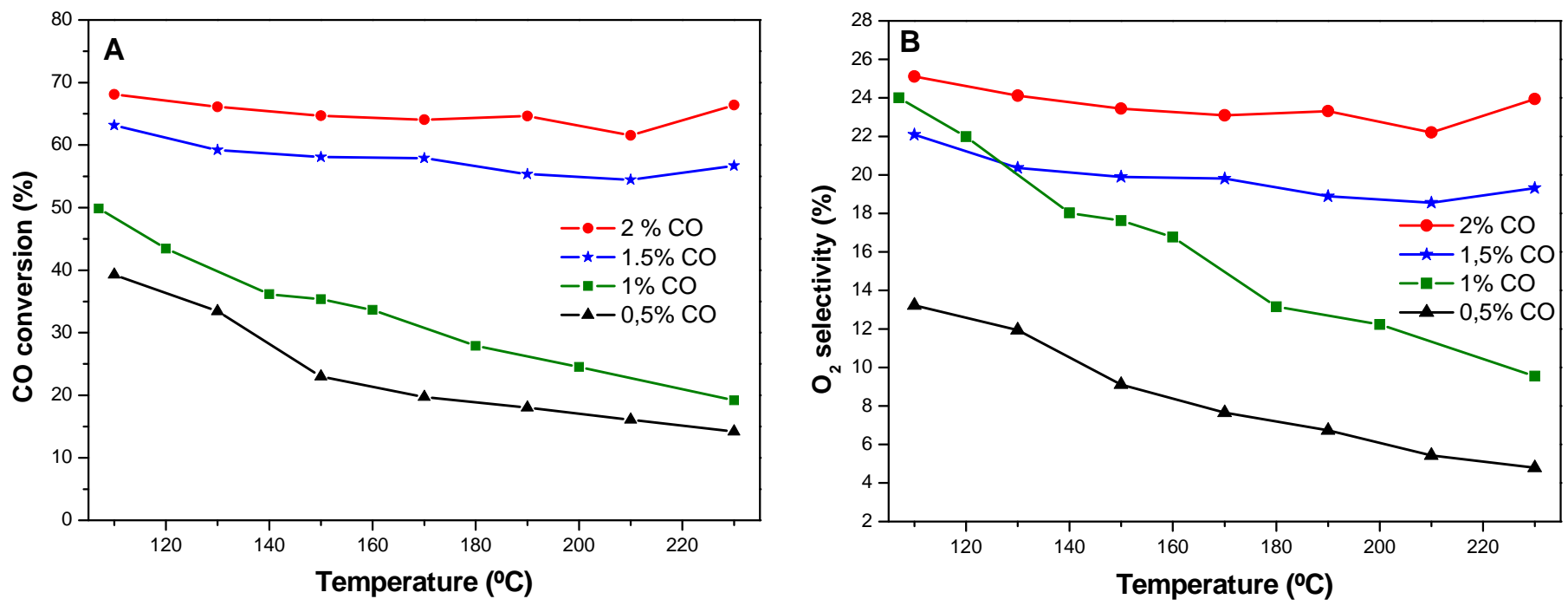
